\title{
SARI KACANG HIJAU DAN MADU MENINGKATKAN NILAI HEMOGLOBIN REMAJA KELAS XI
}

\author{
Green and Honey Bean Sari Increases Hemoglobin Value of Class XI Adolescents
}

\author{
Eka Meiri K. ${ }^{1}$, Aulia ${ }^{2}$,Arisda Candra $\mathrm{S}^{3}$, Emdat Suprayitno ${ }^{4}$, Ratna Indriyani ${ }^{5}$, Ahmani $^{6}$ \\ 1, 2, 3, 4, 5, 6 Fakultas Ilmu Kesehatan Universitas Wiraraja
}

\section{Riwayat artikel}

Diajukan: September 2020

Diterima: Maret 2021.

\section{PenulisKorespondensi: \\ - Eka Meiri K. \\ - Fakultas Ilmu \\ Kesehatan Universitas \\ Wiraraja \\ - ekameiri@wiraraja. ac.id}

\section{Kata Kunci:}

Defisiensi Hb, Sari Kacang

Hijau, Madu
Defisiensi hemoglobin pada remaja mengakibatkan terganggunya pertumbuhan fisik, terganggunya perilaku dan psikologi sehingga dapat mengganggu proses sel otak yang mengakibatkan turunnya daya tahan tubuh, cepat capek dan lapar, tidak fokus saat belajar, turunnya prestasi belajar dan juga dapat turunnya energy dalam bekerja. Hasil studi pendahuluan pada tanggal 12 Maret 2020 di SMAN Gapura pada 10 siswi kelas XI. 5 orang siswi mengatakan kalau sering pusing dan pandangan agak berkunang-kunang, apalagi pada saat menstruasi. 3 orang mengatakan kadang sering lelah disertai dengan jantung berdegub kencang dan 2 orang siswi mengatakan merasa lemas pada saat mentruasi. Ini merupakan penelitian pra eksperimental menggunakan pendekatan one group pre test - post test. Populasi dan sampel pada penelitian ini adalah semua siswi kelas XI yang mengalami anemia ringan sebanyak 35 orang. Teknik sampling menggunakan total sampling.

Pengumpulan data dengan lembar observasi, Analisa data menggunakan uji Wilcoxon. Hasil penelitian menunjukkan bahwa sebelum diberi intervensi semua responden sebanyak 35 orang $(100 \%)$ mengalami anemia ringan. Setelah diberi intervensi sebanyak 32 orang $(91 \%)$ nilai Hbnya meningkat menjadi $\geq 12 \mathrm{gr} / \mathrm{dL}$. Hasil analisis dengan uji wolcoxon menunjukkan bahwa $\mathrm{p}=0,000(\mathrm{p}<0,05)$. Kesimpulan penelitian ini yaitu ada efek mengkonsumsi sari kacang hijau bersama madu pada kenaikan nilai $\mathrm{Hb}$ siswi kelas XI di SMAN Gapura. Diharapkan siswi dapat melakukan upaya preventif terkait anemia pada dirinya

\section{Abstract}

Hemoglobin deficiency in adolescents affected in disruption of physical growth, disruption of behavior and psychology so that it can interfere with brain cell processes that isn decreased endurance, quickly tired and hungry, not focused while studying, decreased learning achievement and can also decrease energy at work. The results of the preliminary study on March 12, 2020 at SMAN Gapura for 10 grade XI students showed. 5 students said that they were often dizzy and had a slightly lightheaded look, especially during menstruation. 3 people said they were often tired, accompanied by a racing heart, and 2 students said they felt weak during menstruation. This was a pre-experimental study with a one group pre test - post test approach. The population and sample in this study were all class XI students who had mild anemia as many as 35 people. The sampling technique used total sampling. Data collection used observation sheets, data analysis used the Wilcoxon test. The results showed that before being given the intervention, 35 respondents $(100 \%)$ had mild anemia.

After being given the intervention, 32 people (91\%) had their $\mathrm{Hb}$ value increased to $\geq 12 \mathrm{gr} / \mathrm{dL}$. The results of analysis with wilcoxon test showed that $\mathrm{p}=$ 0.000 ( $\mathrm{p}<0.05)$. The conclusion of this study is there is an effect of consuming mung bean juice with honey on the increase in $\mathrm{Hb}$ value of class XI students at Gapura Senior High School. It is hoped that students can make preventive measures related to anemia in themselves 


\section{Pendahuluan}

dalam masalah gizi di $\begin{array}{r}\text { Defisiensi } \\ \text { hemoglobin termasuk }\end{array}$ Berdasarkan data dari WHO, anemia yang terjadi pada wanita usia subur (WUS) di negara berkembang sekitar 13\%. (Listiana, 2016). Pengertian dari anemia adalah keadaan penurunan jumlah eritrosit yang menyebabkan jumlah hemoglobin berada dibawah batas normal. Tanda-tandanya antara laian cepat lelah, sering mengantuk, sakit kepala, detak jantung tidak teratur dan tangan dan kaki dingin. (Baiq Nurlaily Utami, 2015) (Yuniarti, Rusmilawaty, 2013)

Defisiensi hemoglobin pada remaja mengakibatkan terganggunya pertumbuhan fisik, terganggunya perilaku dan psikologi sehingga dapat mengganggu proses sel otak yang mengakibatkan turunnya daya tahan tubuh, cepat capek dan lapar, tidak focus saat belajar, turunnya prestasi belajar dan juga dapat turunnya energy dalam bekerja. (Masthalina, 2015) (Baiq Nurlaily Utami, 2015)

Makanan yang mengandung $f e$ dari hewani dan nabati merupakan sumber $f e$ yang tinggi sehingga susah di absorpsi oleh tubuh, oleh sebab itu makanan non heme dibutuhkan dalam jumlah besar supaya bisa memenuhi kebutuhan zat besi setiap harinya. Jika Kurang mengkonsumsi zat protein, vitamin $\mathrm{C}$ dan mengkonsumsi makanan yang menghambat proses absorpsi $f e$ dapat menyebabkan defisiensi hemoglobin. Protein dan vitamin $\mathrm{C}$ berperan penting dalam absorpsi $f e$ di dalam tubuh. Defisiensi hemoglobin yang disebabkan oleh kurangnya cobalamin dan vitamin B9 juga banyak terjadi pada remaja yang disebabkan rendahnya memakan makanan yang mengandung cobalamin dan vitamin B9 (Ospedale and Raffaele, 2017)

Upaya yang dapat dilakukan untuk mencegah terjadiya defisiensi hemoglobin adalah dengan memakan makanan yang komposisinya seperti daging, ikan, ayam, hati, telur, kacang - kacangan, dan tempe serta memakan makanan yang mengandung vitamin $\mathrm{C}$ karena memakan makanan yang banyak berisi vitamin $\mathrm{C}$ dapat meningkatkan penyerapan $f e$. Jambu biji, jeruk, tomat, dan nanas adalah buah yang tinggi kandungan vitamin C-nya. Selain mengkonsumsi makanan yang mengandung vitamin $\mathrm{C}$ juga bisa minum 1 tablet $f e$ setiap hari saat menstruasi sebagai pencegahan terjadinya defisiensi hemoglobin. Sesuai dengan anjuran kemenkes tahun 2016 (Nomor HK.03.03/V/0595/2016) bahwa tablet $f e$ diberikan pada wanita usia subur dan remaja wanita sebanyak 1 tablet setiap minggu untuk diminum. Supaya pemberian tablet $f e$ tepat sasaran dan efektif pemerintah juga menganjurkan untuk menentukan waktu bersama konsumsi tablet $f e$ di sekolah remaja wanita. Pemberian tablet $f e$ pada remaja putri tujuannya adalah untuk memenuhi kebutuhan $f e$ pada remaja putri yang akan menjadi ibu kemudian hari (Indriyani and Suprayitno, 2017). Dengan tercukupinya kebutuhan $f e$ sejak dini, dapat mencegah terjadinya defisiensi hemoglobin pada wanita hamil, pendarahan saat persalinan, BBLR, dan stunting. (Desri Suryani, 2015)

Kacang hijau (Vigna Radiata) bermanfaat untuk mencegah defisiensi $f e$, di dalam $0,1 \mathrm{~kg}$ kacang hijau terkandung 0,124 gram kalsium dan $0,326 \mathrm{mg}$ fosfor, yang berkhasiat untuk memperkuat kerangka tulang. Kacang hijau juga mengandung 19,7-24,2 \% protein dan 5,9-7,8 \% besi. (Salvia, 2019) (Vina Aulia, 2018). Selain itu kacang hijau, minuman yang mengandung mineral tembaga, magnesium, potassium , fosfor, magnesium, $\mathrm{fe}$ dan sodium adalah madu. Madu juga mengandung glukosa $75 \%$, asam organik $8 \%$, protein, enzim, garam mineral $18 \%$, vitamin, biji renik, minyak (Indriyani et al., 2020). Karena kandungan fe yang terdapat pada madu berkhasiat mengatasi defisiensi hemoglobin, madu juga mengandung antibiotik. hal ini sejalan dengan penelitian yang dilakukan oleh Linda Rosita dan Utami Mulyani (2014), mengatakan bahwa ekstra madu mampu meningkatkan nilai hemoglobin (Hb) darah secara in vitro pada tikus putih jantan. (Noor Cholifah, 2018). Prevelansi defisiensi hemoglobin sebanyak 21,7 \% 
yang terjadi di Indonesia dengan penderita defisiensi hemoglobin berusia 5-14 tahun sebanyak $26,4 \%$ dan $18,4 \%$ penderita berusia 15-24 tahun. (Munafiah, Kusyati and

\begin{tabular}{llll}
\hline No & Usia & Jumlah(n) & Pesentase(\%) \\
\hline 1 & 16 Tahun & 18 & $51 \%$ \\
\hline 2 & 17 Tahun & 16 & $46 \%$ \\
\hline 3 & 18 Tahun & 1 & $3 \%$ \\
\hline Total & $\mathbf{3 5}$ & $\mathbf{1 0 0 \%}$ \\
\hline Inayati 2018) & & Sedangkan defisiensi
\end{tabular}

Inayati, 2018). Sedangkan defisiensi hemoglobin yang terjadi pada balita prevelansinya sebanyak $40,5 \%, 50,5 \%$ pada ibu hamil $45,1 \%$ pada ibu nifas, $57,1 \%$ pada remaja putri yang berusia 10-18 tahun dan sebanyak $39,5 \%$ pada usia $19-45$ tahun. Perempuan mempunyai risiko mengalami defisiensi hemoglobin paling tinggi terutama pada remaja putri.(Riskesdas, 2013)

Hasil studi pendahuluan pada tanggal 12 Maret 2020 di SMAN Gapura pada 10 siswi kelas XI. 5 orang siswi mengatakan kalau sering pusing dan pandangan agak berkunang-kunang, apalagi pada saat menstruasi. 3 orang mengatakan kadang sering lelah diserati dengan jantung berdegub kencang dan 2 orang siswi mengatakan merasa lemas pada saat mentruasi.

Dari hasil studi pendahuluan tersebut, peneliti ingin melakukan penelitian tentang efek pemberian sari kacang hijau bersama madu pada kenaikan nilai hemoglobin pada siswi kelas XI di SMAN Gapura.

\section{Metodologi}

Penelitian ini merupakan pra eksperimental dengan rancang bangun one group pre test-post test yaitu melibatkan satu kelompok subjek dengan cara membandingkan hasil pre test dengan post test. Kelompok subjek di ukur dengan menggunakan lembar observasi sebelum dilakukan intervensi, kemudian di observasi lagi setelah diberikan intervensi. (Lusiana, 2015). Populasi pada penelitian ini adalah semua siswi kelas XI yang mengalami anemia ringan di SMAN 1 Gapura yang berjumlah 35 orang. Sampel pada penelitian ini adalah seluruh siswi kelas XI yang menderita anemia ringan berjumlah 35 orang. Analisa data menggunakan uji Wilcoxon. Penelitian ini dilakukan di SMAN I Gapura Bulan Juli 2020.

\section{Hasil dan Pembahasan}

\section{Data Umum}

\section{A.Distribusi Frekuensi Responden Berdasarkan Usia}

Hasil penelitian pada tabel di atas menunjukkan bahwa sebagian besar responden berusia 16 tahun sebanyak 18 orang (51\%) dan sebagian kecil berusia 18 tahun sebanyak 1 orang (3\%).

\section{Data Khusus}

\section{A. Distribusi Frekuensi Responden Berdasarkan Nilai Hb Pada}

\begin{tabular}{lccc}
\hline No & Nilai Hb & Jumlah(n) & Pesentase(\%) \\
\hline 1 & $11-$ & 35 & $0 \%$ \\
& $11,9 \mathrm{gr} / \mathrm{dL}$ & & \\
\hline \multicolumn{2}{l}{ Total } & $\mathbf{3 5}$ & $\mathbf{1 0 0 \%}$ \\
\hline \multicolumn{2}{l}{ Siswi Sebelum } \\
\hline
\end{tabular}

\section{Siswi Sebelum Perlakuan}

Hasil penelitian berdasarkan tabel menyatakan bahwa semua responden sebanyak 35 orang $(100 \%)$ mengalami anemia ringan.

B. Distribusi Frekuensi Responden Berdasarkan Nilai Hb Pada Siswi Sesudah Perlakuan

\begin{tabular}{llcl}
\hline No & Nilai Hb & Jumlah(n) & Pesentase(\%) \\
\hline 1 & $\geq 12 \mathrm{gr} / \mathrm{dL}$ & 32 & $91 \%$ \\
\hline 2 & $\begin{array}{l}11- \\
11,9 \mathrm{gr} / \mathrm{dL}\end{array}$ & 3 & $9 \%$ \\
\hline \multicolumn{2}{l}{ Total } & $\mathbf{3 5}$ & $\mathbf{1 0 0 \%}$ \\
\hline
\end{tabular}

Hasil penelitian berdasarkan tabel di atas menyatakan bahwa 32 orang (91\%) nilai hemoglobinnya mengalami kenaikan. Sedangkan 3 $(9 \%)$ orang nilai hemoglobinnya tetap atau mengalami anemia ringan 


\section{Efek Mengkonsumsi Sari Kacang Hijau Bersama Madu 1) Uji Normalitas}

\begin{tabular}{cccccc}
\hline \multicolumn{3}{c}{$\begin{array}{c}\text { Kolmogorov- } \\
\text { Smirnov }^{\mathrm{a}}\end{array}$} & \multicolumn{3}{c}{ Shapiro-Wilk } \\
\hline Stat & $\mathrm{d}$ & $\mathrm{Si}$ & Stati & $\mathrm{d}$ & $\mathrm{Sig}$ \\
istic & $\mathrm{f}$ & $\mathrm{g}$. & $\mathrm{stic}$ & $\mathrm{f}$ &. \\
.462 & 3 & .0 & .546 & 3 & .00 \\
& 5 & 00 & & 5 & 0 \\
.227 & 3 & .0 & .799 & 3 & .00 \\
& 5 & 00 & & 5 & 0 \\
\hline
\end{tabular}

Hasil uji normalitas berdasarkan pada tabel menyatakan bahwa data tidak berdistribusi normal baik dengan menggunakan uji Kolmogrov-Smirrov uji Shapiro-Wilk , dimana nilai signifikan (p) pada uji KolmogorovSmirnov dan uji Shapiro-Wilk adalah $0.00(\mathrm{p}<0.05)$, yang artinya bahwa data berdistribusi tidak normal.

\section{2) Uji Wilcoxon}

\begin{tabular}{lcc}
\hline Kelompok & $\begin{array}{c}\text { HB Sesudah- } \\
\text { HB Sebelum }\end{array}$ \\
\hline \multicolumn{2}{c}{$\mathrm{Z}$} & \\
$\begin{array}{l}\text { Asymp. } \\
\text { tailed) }\end{array}$ & Sig.(2- & $-4.942^{\mathrm{b}}$ \\
& .000 \\
\hline
\end{tabular}

Berdasarkan tabel diatas Menunjukkan bahwa sesudah konsumsi sari kacang hijau dan madu sebagian besar nilai $\mathrm{Hb}$ meningkat sebanyak 33 responden dan sebagian nilai $\mathrm{Hb}$ tetap sebanyak 2 responden. Dari hasil analisis data didapatkan bahwa Asymp.Sig.(2-tailed) bernilai 0.000 . Karena nilai 0.000 ebih kecil dari <005,maka dapat disimpulkan bahwa HO diterima. Artinya ada perbedaan antara nilai $\mathrm{HB}$ sebelum konsumsi sari kacang hijau dan madu, sehinga dapat disimpulkan bahwa ada efek samping atau pegaruh mengkonsumsi sari kacang hijau dan madu terhadap kenaikan nilai $\mathrm{Hb}$ Siswi Kelas IX di SMAN I Gapura

\section{Pembahasan}

1. Nilai $\mathrm{Hb}$ Siswi Kelas XI Sebelum Mengkonsumsi Sari Kacang Hijau dan Madu

Hasil penelitian menunjukkan bahwa siswi kelas XI sebanyak 35 orang mengalami anemia ringan. Remaja perempuan berakibat lebih besar untuk mengalami defisiensi hemoglobin dibandingkan dengan remaja laki-laki. Kurangnya konsumsi gizi seimbang, faktor pertumbuhan, adanya menstruasi setiap bulan sehingga membuat remaja wanita membutuhkan asupan Fe lebih banyak (Permatasari and Suprayitno, 2020). (Indriyani et al., 2020)Diet yang salah juga menjadi faktor penyebab anemia pada remaja perempuan. Nilai Hemoglobin adalah indikator yang praktis digunakan untuk menentukan status anemia. (Yuniarti, Rusmilawaty, 2013) (Basith, Agustina and Diani, 2017)

Didalam tubuh manusia zat besi berperan sebagai katalisator proses pembentukan hemoglobin, oleh karena itu jika seorang remaja kurang mengkomsumsi makanan yang mengandung zat besi dapat menyebabkan defisiensi zat besi (Pratiwi, Suprayitno and Kristanti, 2018). Banyak dari remaja yang asupan gizinya tidak tepat seperti suka makan es, pentol, coklat, gorengan, permen dan makan tidak teratur karena melakukan aktivitas yang padat sering menyebabkan terjadi gangguan pada pencernaan, sehingga proses absorpsi zat besi didalam tubuh jadi terganggu.(Daris et al., 2013)

Untuk menghindari terjadinya defisiensi $f e$ sudah dilakukan oleh pemerintah, yaitu melalui upaya preventif melalui program suplementasi besi yang diberikan secara gratis. Untuk menanggulangi dan melakukan pencegahan anemia dilakukan perbaikan asupan nutrisi 
yaitu dengan makan pagi, siang dan malam secara tepat waktu dan dengan menu seimbang. (Dea Indartanti, 2014)

Adanya kebiasaan diet ketat oleh remaja wanita sebagai upaya untuk langsing yaitu dengan pembatasan konsumsi makanan tertentu padahal hal tersebut tidak baik untuk kesehatan dimana dimasa remaja memerlukan zat-zat tertentu untuk proses peertumbuhan remaja hal ini sejalan dengan penelitian sebelumnya bahwa salah satu pemicu terjadinya anemia adalah pola makan yang salah yaitu mengkonsumsi makanan rendah kandungan besi dan vitamin, khususnya folat. (Baiq Nurlaily Utami, 2015)

Factor risiko lain adalah seringnya meminum teh maupun kopi pada saat setelah makan. Hal ini sejalan dengan peneliti sebelumnyayang engatakan idealnya minum the adalah satu jam sebelum ataupun sesudah makan karena teh dapat menghambat proses absorpsi fe sebesar $64 \%$, ini terjadi karena di dalam teh mengandung tanin dimana tanin bersifat mengikat mineral. Sedangkan kopi dapat menghabat proses absropsi zat besi sebesar 39\%. Oleh sebab itu pentingya remaja untuk mengetahui hal itu melalui tenakes.(Listiana, 2016)

2. Nilai Hb Siswi Kelas XI Setelah Mengkonsumsi Sari Kacang Hijau dan Madu

Hasil penelitian menunjukkan bahwa sebanyak 33 responden mengalami kenaikan nilai $\mathrm{Hb}$ menjadi tidak anemia dan sebanyak 2 orang nilai Hbnya tetap anemia ringan. Salah satu jenis makanan yang bisa menghalangi defisiensi fe adalah kacang hijau. Pada kacang hijau mengandung zat-zat yang diperlukan untuk pembentukan sel darah sehingga dapat mengatasi akibat dari penurunan nilai hemoglobin. Kacang hijau mengandung fitokimia yang bermanfaat untuk proses hematopoiesis. Kacang hijau juga mengandung vitamin dan mineral. Kacang hijau juga mengandung kalsium, fosfor, besi, natrium dan kalium banyak terdapat pada kacang hijau. Sedangkan madu dari sejak dahulu sudah terkenal manfaatnya untuk kesehatan tubuh, karena kandungan mineral pada mampu mampu meningkatkan nilai $\mathrm{Hb}$ melalui proses penyerapan kalsium sehingga berdampak pada kenaikan nilai $\mathrm{Hb} \mathrm{Hal}$ ini sejalan dengan peneliti sebelumnya yang mengatakan pada saat madu di konsumsi setiap hari mampu meningkatkan energy yang berakibat pada peningkatan jumlah $\mathrm{Hb}$ dan mencegah terjadinya defisiensi fe.(Noor Cholifah, 2018)

Pada responden yang nilai Hemoglobinnya tidak meningkat bisa disebabkan oleh faktor suplai nutrisi yang tidak mencukupi kebutuhan gizi pada remaja wanita. Suplai zat gizi sehari-hari sangat dipengaruhi oleh kebiasaan makan. pola makan, asupan makanan yang tidak adekuat selain itu aktivitas fisik sehari-hari juga berpengaruh pada kejadian anemia. Faktor lain juga bisa disebabkan karena adanya siklus mentruasi pada remaja wanita. Fe yang hilang waktu menstruasi sesuai dengan jumlah darah yang keluar setiap siklus menstruasi. Berkurangnya $f e$ menyebabkan simpanan $f e$ semakin menurun, keadaan ini disebut iron depleting state. Jika kekurangan $f e$ berlanjut terus maka simpanan $f e$ menjadi kosong sama sekali hal ini yang menyebabkan defisiensi fe pada remaja putri

3. Pengaruh Mengkonsusmsi Sari Kacang Hijau dan Madu Terhadap Kenaikan Nilai $\mathrm{Hb}$ pada siswi kelas XI.

Berdasarkan hasil uji Wilcoxon di dapat Diperoleh $\rho$ value sebesar 
0,000, hal ini menunjukkan bahwa nilai $\rho$ value $<0,05$. Sehingga disimpulkan bahwa $\mathrm{H} 1$ diterima dan Ho ditolak, yaitu ada efek mengkonsumsi kacang hijau dan madu terhadap kenaikan nilai $\mathrm{Hb}$ pada siswi kelas XI di SMAN 1 Gapura yang mengalami anemia ringan. Dengan mengkonsu sari kacang hijau $100 \mathrm{ml}$ selama 7 hari dapat meningkatkan nilai kadar $\mathrm{Hb}$ dikaenakan didalam kacang hijau banyak mengandung Vitamin $\mathrm{C}$ dimana manfaat vitamin $\mathrm{C}$ adalah dapat meningkatkan kemampuan absorpsi fe non hame sebesar 4x lipat. Vitamin $\mathrm{C}$ mereduksi besi ferri (Fe3+)menjadi ferro $(\mathrm{Fe} 2+)$ di usus halus sehingga mudah diabsorbsi, proses reduksi tersebut akan menjadi semakin besar apabila $\mathrm{pH}$ di dalam lambung semakin meningkat sehingga dapat meningkatkan penyerapan zat besi hingga $30 \%$. Vitamin C juga dapat membebaskan fe dengan menghambat proses pembentukan hemosiderin yang sukar dimobilisasi. Protein, karbohidrat, dan lemak yang terdapat di dalam kacang hijau berperan pada proses sintesis hemoglobin. Selain itu Kacang hijau juga mengandung vitamin A sebesar 7 mcg dalam 100 gramnya.jika defisiensi vitamin A menyebabkan defisiensi fe menjadi lebih buruk. Hal ini sejalan dengan penelitian yang dilakukan oleh Amalia (2016) menyatakan bahwa minuman kacang hijau dapat meningkatkan kadar Hemoglobin dalam darah secara signifikan karena mengandung zat besi yang tinggi, asam folat, seng, vitamin $C$, vitamin $A$ yang sangat berperan dalam pembentukan sel-sel darah merah, sehingga dapat meminimalisir terjadinya kekurangan kadar Hemoglobin dalam tubuh. (Santoso, Mochamad Budi, 2018)

Madu juga banyak mengandung Vitamin C, Vitamin A, fe dan vitamin
B12 yang dapat meningkatkan hemoglobin di dalam darah hal ini sejalan dengan penelitian yang dilakukan oleh peneliti lain bahwa dengan mengkonsumsi pisang sebanyak 200gram dan 30 mili madu dapat mempengaruhi peningkatan nilai $\mathrm{Hb}$ pada ibu hamil yang mengalami anemia. (Lestari Sri, 2020). Akibat anemia pada remaja wanita meliputi gangguan pertumbuhan fisik, gangguan perilaku serta gangguan emosional. Dapat mempengaruhi juga sel otak sehingga mengakibatkan daya tahan tubuh menurun, kurang konsentrasi dan lemas.

\section{Simpulan}

Berdasarkan hasil dan pembahasan pada penelitian ini dapat disimpulkan sebagai berikut:

a. Nilai $\mathrm{Hb}$ siswi kelas XI sebelum konsumsi sari kacang hijau dan madu rata-rata 11-11,9 gr\%

b. Nilai Hb siswi kelas XI setelah konsumsi sari kacang hijau dan madu rata-rata nilai Hbnya menjadi $12 \mathrm{gr} \%$.

c. Ada efek atau pengaruh dari konsumsi sari kacang hijau dan madu pada siswi kelas XI yang mengalami anemia ringan dengan uji analisis Wilcoxon yaitu hasil $\mathrm{p}=0,000(\mathrm{p}<0,05)$.

\section{Daftar Pustaka}

Baiq Nurlaily Utami, D. (2015) 'Hubungan Pola makan dan Pola Menstruasi Dengan Kejadian Anemia Remaja Putri', Jurnal Keperawatan Soedirman (The Soedirman Journal of Nursing), 10(2), pp. 67-75.

Basith, A., Agustina, R. and Diani, N. (2017) 'Faktor-Faktor Yang Berhubungan Dengan Kejadian Anemia Pada Remaja Putri', Dunia Keperawatan, 5(1), p. 1. doi: 10.20527/dk.v5i1.3634.

Daris, C. et al. (2013) 'Hubungan Antara Status Gizi dengan Anemia pada Remaja Putri di Sekolah Menengah Pertama Muhammadiyah 3 Semarang.', 1, pp. 3-7. 
Dea Indartanti, dkk (2014) 'Hubungan Status Gizi Dengan Kejadian Anemia Pada Remaja Putri', 3, pp. 33-39.

Desri Suryani, D. (2015) 'Analisis Pola Makan dan Anemia Gizi Besi Pada Remaja Putri KOta Bengkulu', pp. 11-18.

Indriyani, R. et al. (2020) 'Pengaruh Konsumsi Sari Buah Jambu Merah dan Madu terhadap Kenaikan Nilai HB pada Ibu Hamil di Tempat Praktek Mandiri Bidan Muarofah Surabaya', WIRARAJA MEDIKA, 10(1), pp. 36-40. doi: https://doi.org/10.24929/fik.v10i1.938.

Indriyani, R. and Suprayitno, E. (2017) 'Hubungan Postpartum Blues Dengan Keputusan Menggunakan KB Pasca Nifas Di UPT Puskesmas Lenteng', Journal of Health Science (Jurnal Ilmu Kesehatan), 2(2), pp. 7075. doi: https://doi.org/10.24929/jik.v2i2.552.

Lestari Sri, D. (2020) 'Pengaruh Pemberian Jus Pisang Ambon Dan Madu Terhadap Kenaikan Kadar Hemoglobin Pada Ibu Hamil Dengan Anemia Di Puskesmas Mrican Kota Kediri', Java Health Journal, (1).

Listiana, A. (2016) 'Analisis Faktor-Faktor Yang Berhubungan dengan Kejadian Anemia Gizi Besi Pada Remaja Putri di SMKN 1 Terbanggi Besar Lampung Tengah', pp. 455-469.

Lusiana, d. (2015) Metodelogi Penelitian Kebidanan. Yogyakarta : Deepublish.

Masthalina, H. (2015) 'Pola Konsumsi (Faktor Inhibitor Dan Enhancer Fe) Terhadap Status Anemia Remaja Putri', Jurnal Kesehatan Masyarakat, 11(1), p. $80 . \quad$ doi: 10.15294/kemas.v11i1.3516.

Munafiah, D., Kusyati, E. and Inayati, N. (2018) 'Pemberian Tablet Fe dan MAMA ( Madu Kurma ) Meningkatkan Kadar Hemoglobin Kehamilan Aterm dalam Persiapan Persalinan', pp. 26-33.

Noor Cholifah, A. W. (2018) 'Aplikasi Pemberian adu Terhadap Peningkatan Hemoglobin ( $\mathrm{Hb})$ Pada Remaja Putri Yang Mengalami Anemia', (September 2006), pp. 533-539.

Ospedale, I. and Raffaele, S. (2017) 'Iron Deficiency Anemia Disclosure for Clara Camaschella Vifor Pharma advisory board'.

Permatasari, D. and Suprayitno, E. (2020) 'Implementasi Kegiatan Pendidik Sebaya dan Konselor Sebaya dalam Upaya Pencegahan Triad KRR di Pusat Informasi dan Konseling Remaja', Jurnal Ners dan Kebidanan (Journal of Ners and Midwifery), 7(1), pp. 143-150.

Pratiwi, I. G. D., Suprayitno, E. and Kristanti, A. N. (2018) 'GAMBARAN MINAT IBU DALAM MEMILIH KB IMPLAN DI DESA KARANG NANGKA KECAMATAN RUBARU KABUPATEN SUMENEP', Journal Of Health Science (Jurnal Ilmu Kesehatan), 3(2), pp. 85-90.

Riskesdas (2013) Kemenkes RI. Hasil Riset
Kesehatan Dasar. Jakarta: Jakarta: Badan Penelitian dan Pengembangan Kesehatan.

Salvia, N. (2019) 'Pengaruh Pemberian Sari Kacang Hijau Terhadap Kadar Hemoglobin Ibu Hamil Di Puskesmas Lembo Konawe Utara', 53(9), pp. 1689-1699. doi: 10.1017/CBO9781107415324.004.

Santoso, Mochamad Budi, D. (2018) 'Pengaruh sari kacang hijau ( vigna radiata) terhadap kadar hemoglobin anak usia sekolah dengan anemia defisiensi zat besi 1', JMCRH, 3(2), pp. 108117.

Vina Aulia, dkk (2018) 'Pengaruh Pemberian Sari Kacang Hijau (Vigna Radiata) Terhadap Kadar Hemoglobin Ibu Hamil Anemia.', pp. 53-60.

Yuniarti, Rusmilawaty, T. T. (2013) 'Hubungan AntaraKepatuhan Minum Tablet Fe Dengan KEjadian Anemia Pada Remaja Putri di MA Darul Imad Kemanatan Tatah Makmur Kabupaten Banjar', 2(1), pp. 2011-2016. 